\title{
Yetiştirici Koşullarında Kıvırcık Irkı Koyunlarda Süt Verim Özelliklerinin Belirlenmesi
}

\author{
Hilal AKGÜN1 Mehmet KOYUNCU2 ${ }^{\mathscr{9}}$ \\ 1Ziraat Yüksek Mühendisi, Balıkesir, ${ }^{2}$ Bursa Uludağ Üniversitesi, Ziraat Fakültesi, Zootekni Bölümü, Bursa \\ ${ }^{1}$ https://orcid.org/0000-0001-5563-9205, ${ }^{2}$ https://orcid.org/0000-0003-0379-7492 \\ $\bowtie$ : koyuncu@uludag.edu.tr
}

\begin{abstract}
ÖZET
Bu araştırma yetiştirici koşullarında bulunan Kıvırcık koyunlarında süt verim ve kalitesini ortaya koymak amaciyla yürütülmüştür. Araştırmada yaşları 3. ve 4. laktasyondaki toplam 38 baş Kıvırcık koyunu kullanılmıştır. Elde edilen sonuçlara göre günlük ortalama süt verimi $495.5 \mathrm{~g} / \mathrm{gün}$ olup, süt kontrol dönemleri itibariyle çok geniş bir varyasyon göstermiştir. Benzer durum somatik hücre sayısında da görülmüş ve bu değer 25.231-8.000.000 adet/ml arasında değişim göstermiştir. Kontrol dönemlerinde alınan süt örneklerinde yağ, yağsız kuru madde, protein, laktoz, yoğunluk, iletkenlik ve $\mathrm{pH}$ değerleri sirasıyla \%7.7, \%11.2, \%5.8, \%4.51, $1.033 \mathrm{gcm}^{3-1}, 3.9 \mathrm{mS} \mathrm{cm}$ ${ }^{1}$ ve 6.90 olarak bulunmuştur.
\end{abstract}

\section{Determination of Milk Yield Characteristics in Kıvircık Sheep under the Breeder Conditions}

\section{ABSTRACT}

This study was conducted to determine the milk yield and quality of Kivircik sheep under breeders' conditions. A total of 38 heads of Kivircık sheep in $3^{\text {th }}$ or $4^{\text {th }}$ lactation were used in the study. According to the results the mean daily milk yield was 495.5 g/day which was considered as a very wide variation in terms of milk control periods. Similar satiation was seen in somatic cell count which was ranged between $25.231-8.000 .000$ units $/ \mathrm{ml}$. Fat, solids not fat, protein, lactose, density, conductivity and $\mathrm{pH}$ values of milk samples taken during the control periods were found as $7.7 \%, 11.2 \%, 5.8 \%, 4.51 \%$, $1.033 \mathrm{gcm}^{3-1}, 3.9 \mathrm{mS} \mathrm{cm}^{-1}$ and 6.90 , respectively.
Araştırma Makalesi

$\begin{array}{ll}\text { Makale Tarihçesi } \\ \text { Geliş Tarihi } & : 07.02 .2020 \\ \text { Kabul Tarihi } & : 09.04 .2020\end{array}$

Anahtar Kelimeler

Kıvircık

Süt verimi

Kalite özellikleri

To Cite : Akgün H, Koyuncu M 2020. Yetiştirici Koşullarında Kıvırcık Irkı Koyunlarda Süt Verim Özelliklerinin Belirlenmesi. KSÜ Tarım ve Doğa Derg 23 (5): 1406-1413. DOI: 10.18016/ksutarimdoga.vi.686319.

\section{GİRIŞ}

Süt, canlının yaşamını sürdürebilmesi, gelişmesi ve verimli olabilmesi için ihtiyaç duyulan tüm maddeleri tam ve dengeli olarak içerisinde bulunduran besin maddesidir. Dünyanın birçok ülkesinde süt denildiğinde inek sütü akla gelirken koyun sütü özellikle Asya, Afrika ve bazı Avrupa ülkelerindeki yetiştiriciler için önemli bir gelir kaynağı durumundadır. Türkiye'de ise küçükbaş hayvanlardan elde edilen süt, ağırlıklı olarak ekstansif veya yarı entansif koşullarda faaliyet gösteren işletmelerden genellikle de elle sağım yöntemi ile üretilmektedir. Koyun sütü, sahip olduğu besin maddesi içerikleri ile özellikle İsrail, İtalya, Fransa, İspanya ve Yunanistan gibi ülkelerde oldukça önemli bir yere sahiptir. Dünyaca ünlü koyun ve keçi peynirleri bu ülkelerde yetiştirilen koyun ve keçilerin sütlerinden elde edilmektedir.

Dünya toplam süt üretiminde koyun sütünün düşük bir pay almasına rağmen, özellikle Türkiye'nin de dâhil olduğu Akdeniz ülkelerinde farklı koyun peynirlerinin üretildiği görülmektedir. Türkiye toplam süt üretimi yaklaşık 22 milyon ton/yıl olup, bunun \% 90,6'sı sığır, \% 6,5’’ koyun, \% 2,5’i keçi ve \% 0,3’ü ise manda sütünden oluşmaktadır. Türkiye koyun sütü üretimi 2018 yılı verilerine göre yaklaşık 1,4 milyon ton olup, sağılan koyun başına ortalama süt verimi 77 kg'dır (Tüik, 2018). Türkiye'de koyun sütü üretimindeki temel belirleyici faktör, sağımı gerçekleştirecek işgücü varlığına ve elde edilen sütün değerlendirebilme koşullarına bağlı olarak değişkenlik göstermektedir. Toplam süt üretiminde geçen ylllar içinde koyun sütünün payının düşmesinde koyun varlığındaki değişimlere bağlı üretiminin azalmasının yanında, toplam süt üretiminde önemli bir paya sahip olan sığırların süt verimindeki yükselmesinin de etkisi vardır.

Koyun sütü; yağ, protein, mineral maddeler ve dolayısıyla kuru madde bakımından zengin bir süt olup, bileşimi \% 7.9 yağ, \%12 yağsız kuru madde, \%4.9 laktoz, \%6.2 protein, \%4.2 kazein ve 0.9 külden oluşmaktadır. Inek ve keçi sütü ile karşılaştırıldığında 
en yüksek kuru madde içeriğine sahip olan koyun sütüdür (Park ve ark. 2007).

Türkiye'de koyun yetiştiriciliğinin ağırlıklı olarak ekstansif koşullarda sürdürülmesi elde edilen sütün miktarı ve kalitesine etkilemektedir. Kaliteli bir süt üretimi için öncelikle koyunların sağlıklı bir meme yapısına sahip olmalarının yanında ve sağım öncesi ve sonrası sütün maruz kaldığı çevresel koşullar da büyük önem taşımaktadır. Kaliteli süt üretme noktasında sütteki somatik hücre sayısı meme sağllğ açısından önemli bir kriterdir. Birçok ülkede süt kalitesinin belirlenmesinde somatik hücre sayısı (SHS) önemli bir belirteç olarak kullanılmaktadır. SHS uygulamasının laktasyon boyunca düzenli izlenmesi özellikle mastitis temelli ortaya çıkan verim kayıpları ve tedavi uygulamalarm maliyetini azaltması noktasında üreticiye önemli avantajlar sağlamaktadır. Diğer taraftan süt verimi ve kalitesi yönünde yapılan kontroller, süt veriminin arttırılması için yapılan seleksiyon çalışmalarına veri sağlanmasının yanında damızlık seçiminde önemli bir kriterdir.

$\mathrm{Bu}$ çalışmada, yetiştirici koşullarındaki Kıvırcık ırkı koyunlarda süt verimi, süt kalite özellikleri, meme ölçüleri, meme puanlama ve parametreleri ile bu özelliklerin birbirleriyle olan ilişkileri araştırılmıştır. Çalışma ile özellikle meme tipleri ve sütteki SHS bakımından yerli koyun ırkları ile yapılan sınırlı sayıdaki araştırmaya katkı da sağlanacaktır.

\section{MATERYAL ve YÖNTEM}

Araştırma, Balıkesir ili Balya ilçesinde bulunan özel bir koyunculuk işletmesinde yürütülmüştür. Araştırmada 3-4. laktasyon döneminde olan toplam 38 baş Kıvırcık koyununun, süt verimi ve süt kalitesi değerlendirilmiştir. Koyunlara, ilkbahar ve yaz aylarında herhangi bir ek yemleme yapılmaksızın sadece meraya dayalı bir yetiştirme sistemi uygulanmıştır. Mart-Ağustos ayları arasında koyunlar ağıla sabah ve aksam sadece sağım için getirilmiş ve geriye kalan zamanda ise merada otlatılmış olan koyunlar Eylül-Kasım ayları arasında ise koyunlar merada yayılmaya devam etmişlerdir. Aralık-Şubat ayları arasında gebeliğin son dönemi ve doğumun yaklaşmasından dolayı meraya ilave olarak koyunlara ortalama $300 \mathrm{~g} / \mathrm{baş} \mathrm{ek} \mathrm{yemleme} \mathrm{yapılmıştır.} \mathrm{Ağıllara}$ alınan koyunlara ek olarak yaz mevsiminde depolanan arpa ezmesi, silaj, çayır kuru otu ve kıraç ot samanı sabah ve aksam yemliklere dökülerek hayvanlara serbest olarak verilmiştir. Hayvanlar bu dönemlerde her istedikleri zaman temiz suya ulaşabilmişlerdir. Ayrıca mineral madde gereksinimleri ağıl içerisine yalama taşları ve kaya tuzu koyularak karşılanmıştır. Koyunların doğumları Ocak ayı sonunda başlamış ve Şubat ayının sonuna kadar devam etmiştir. Koyunlarda sağım işlemi kuzuların analarından tamamen ayrıldıkları Nisan ayının ikinci yarısında başlanmıştır. Doğum dönemleri farklı olsa da sağıma tüm koyunlar aynı zamanda başlamıştır. Sağımlar kotra adı verilen ve iki koyunun girebildiği bölmelerde gerçekleştirilmiştir. Sağım işlemi sabah ve akşam olmak üzere günde iki defa ve elle sağım şeklinde gerçekleştirilmiştir. Sürüde sağım uygulaması süt veriminin azalmaya başladığı Temmuz ayının ilk günlerinde günde tek sağıma düşürülmüş ve Ağustos ayı sonunda ise sağım işlemi sonlandırılarak hayvanlar kuruya çıkarılmıştır.

Koyunların laktasyon sürelerini hesaplayabilmek için doğum yaptıkları tarih, (laktasyona başlama) ve kuruya çıkma tarihleri kayıt edilmiştir. Araştırma materyali koyunlar, kuzuları sütten kesildikten sonra (yaklaşık 2 ay) sağılmaya başlanmıştır. İlk süt alma işlemi kuzuların sütten kesildiği gün yapılmıştır ve laktasyon boyunca 15 günlük periyotlar halinde laktasyon döneminin sonuna kadar devam edilmiştir (6 dönem). Kontrollerde günlük süt verimi 100 ml’nin altında düşen koyunların kuruya çıktıkları kabul edilmiş ve değerlendirme dışı bırakılmıştır. Kontrol dönemlerindeki sağım işlemi esnasında süt miktarları belirlenirken aynı zamanda her koyuna ait sağılan sütlerden analiz için 50 ml'lik tüplere süt örnekleri alınmıştır. Alınan süt örneklerinin tüplere aktarılması aşamasında her hayvandan için iki adet süt örneği (2 tüp) hazırlanmıştır. Örneklerden biri süt kompozisyonunun belirlenmesi, diğer süt örneği ise SHS tayini için kullanılmıştır. Kuzuların emdiği sütü tahmin ve laktasyon süt verimi (LSV)'nin hesaplanmasinda ilk önce deneme boyunca kontrol günü süt verimlerinden ve kontrol aralığından yararlanarak Trapez yöntemine göre sağılan süt miktarı bulunmuştur. İkinci olarak kuzuların emdiği dönemdeki süt verimi tahmin edilmiştir. Bunu için interpolasyon yöntemi uygulanmıştır. $\mathrm{Bu}$ yönteme göre koyunların süt emme dönemi boyunca günlük ilk kontrollerdeki kadar süt verdikleri kabul edilmiştir. Her koyun için süt emme süresi ile ilk kontrol süt verimi çarpılarak sağılan süt miktarına eklenmiş ve LSV tahmin edilmiştir (Icar, 2014).

Trapez yöntemi;

$L S V=k_{1} x A+\sum_{i=1}^{n} \frac{k_{i}+k_{i+1}}{2} x a_{i}$

LSV: Laktasyon süt verimi $(\mathrm{kg})$

$\mathrm{k}_{\mathrm{i}}$ : i. kontrolde saptanan verim $(\mathrm{kg})$

$a_{i}$ : i. dönem uzunluğu (gün)

A: doğum ile ilk kontrol arası süre (gün)

$\mathrm{n}$ : kontrol sayısı

$\mathrm{k}_{1}: 1$. kontrolde saptanan verim $(\mathrm{kg})$

Alınan süt örneklerin de yă̆, yağsız kuru madde, yoğunluk, protein, laktoz, iletkenlik ve $\mathrm{pH}$ değerleri (11 dönem) Milkana-Multi-Test cihazında belirlenmiştir. Sütte ilk somatik hücre sayısı kuzuların sütten kesildiği tarihte yapılmıştır. Bu kontroller laktasyon süresi boyunca 15 günlük periyotlar halinde laktasyon döneminin sonuna kadar 
devam etmiştir. Somatik hücrelerin sayımı Somatos Mini marka somatik hücre sayım cihazı ile yapılmıştır.

Elde edilen veriler Minitab 17.0 paket programı ile aşağıdaki matematik model kullanılarak değerlendirilmiştir (Minitab, 2014). Koyunların süt verimi ve kompozisyonu değerlendirmek için aşağıdaki matematiksel model kullanılmıştır.

$\mathrm{Y}_{\mathrm{ijkl}}=\mathrm{m}+\mathrm{ai}_{\mathrm{i}}+\mathrm{b}_{\mathrm{j}}+\mathrm{c}_{\mathrm{k}}+\mathrm{e}_{\mathrm{ijkl}}$

$\mathrm{Y}_{\mathrm{ijkl}}=\mathrm{i}$. dönemdeki j. doğum tipindeki, k. canlı ağırlığındaki ölçülen değer

$\mathrm{m}=$ popülasyonun beklenen ortalamasını

$a_{i}=i$. dönemin etkisini

$\mathrm{b}_{\mathrm{j}}=\mathrm{j}$. doğum tipinin etkisini

$c_{\mathrm{k}}=\mathrm{k}$. canlı ağırlığının etkisini

$\mathrm{e}_{\mathrm{ijkl}}=$ Ortalaması sifir standart sapması $\sigma_{e}^{2}$ olan hata etkisini göstermektedir.

İnteraksiyonlar ilk önce modele dâhil edilmiştir ancak önemli bulunmadıkları için çıkarılmıştır.

LSV'ni tahmin etmek için kontrol günü süt verimi bağımsız değişken olarak alınmış ve modeli aşağıda verilen doğrusal regresyon analizi yapılmıştır. Buradaki regresyon katsayısı günlük süt verimindeki bir birim değişikliğin laktasyon süt verimine etkisini göstermektedir.

$\mathrm{Y}_{\mathrm{ij}}=\mathrm{a}+\mathrm{b}_{1} \mathrm{GSV}_{\mathrm{i}}+\mathrm{e}_{\mathrm{ij}}$

$\mathrm{Y}_{\mathrm{ij}}=\mathrm{LSV}, \mathrm{kg}$

$\mathrm{a}=$ regresyon denkleminin sabiti

$\mathrm{b}_{\mathrm{i}}=$ ilk kontrol süt veriminin (g) $\mathrm{LSV}(\mathrm{kg})$ üzerine regresyon katsayısı'nı, $\mathrm{GSV}_{\mathrm{i}}=$ ilk kontrol süt verimi (g)'ni, e eij = hatayı göstermektedir.

\section{BULGULAR ve TARTIŞMA}

Koyunlarda süt verimi üzerine genotip, bakımbeslenme, vücut kondisyonu, doğum tipi, yaş, yıl, işletme, mevsim ve canlı ağırlık gibi birçok faktör Çizelge 1. Süt verim ve kalite özellikleri

Table 1. Milk yield and quality characteristics

\begin{tabular}{|c|c|c|c|c|c|c|}
\hline Özellikler (Parameters) & $\mathbf{N}$ & $\bar{x} \pm S \bar{x}$ & SD & CV\% & Min. & Max. \\
\hline Süt verimi, g gün-1 (Milk Yield, $g$ day $\left.{ }^{-1}\right)$ & 228 & $495.5 \pm 19.40$ & 292.4 & 59.01 & 103.6 & 1554.0 \\
\hline $\mathrm{LSV}, \mathrm{kg}(L M Y, \mathrm{~kg})$ & 38 & $101.4 \pm 4.88$ & 30.07 & 29.65 & 63.71 & 185.31 \\
\hline $\mathrm{LS}$, gün $(L P$, day $)$ & 38 & $154.8 \pm 1.08$ & 6.63 & 4.28 & 142 & 169 \\
\hline SHS, adet $\mathrm{ml}^{-1}\left(S C C\right.$, number $\left.\mathrm{ml}^{-1}\right)$ & 418 & $49968 \pm 61665$ & 1260744 & 25231 & 1000 & 8000000 \\
\hline LogSHS $(\log S C C)$ & 418 & $4.9 \pm 0.04$ & 0.79 & 16.09 & 3.0 & 6.9 \\
\hline Yağ, \% (Fat, \%) & 418 & $7.7 \pm 0.10$ & 2.01 & 26.26 & 2.65 & 15.3 \\
\hline Yağsiz KM, \%(Solids non fat, \%) & 418 & $11.2 \pm 0.04$ & 0.77 & 6.89 & 8.21 & 14.5 \\
\hline Yoğunluk, g cm ${ }^{3-1}$ (Density, $\mathrm{g} \mathrm{cm}^{3-1}$ ) & 418 & $1.033 \pm 0.0002$ & 0.0040 & 0.39 & 1.0209 & 1.0473 \\
\hline Protein, \% (Protein,\%) & 418 & $5.8 \pm 0.03$ & 0.64 & 11.07 & 3.34 & 8.73 \\
\hline Laktoz, \% (Lactose,\%) & 418 & $4.5 \pm 0.01$ & 0.12 & 2.72 & 3.61 & 5.54 \\
\hline İletkenlik, $\mathrm{mS} \mathrm{cm}^{-1}$ (Conductivity, $\mathrm{mS} \mathrm{cm}^{-1}$ ) & 418 & $3.9 \pm 0.04$ & 0.78 & 19.84 & 2.61 & 11.9 \\
\hline $\mathrm{pH}$ & 418 & $6.9 \pm 0.01$ & 0.12 & 1.79 & 6.56 & 7.5 \\
\hline
\end{tabular}

Kontrol dönemi, canlı ağırlık ve doğum tipinin araştırmada incelenen süt verimi ve özelliklere etkisi ile bu faktörlere ait en küçük kareler ortalamaları Çizelge 2'de verilmiştir. Bu çalışmada ilk 5 dönemde koyunlar ile kuzular birlikte oldukları için verimli bir şekilde günlük süt verimlerinin etkilidir. Diğer çiftlik hayvanlarında olduğu gibi koyunlarda da, yaşam boyunca saptanan ekonomik değeri olan özellikler arasında, ırktan ırka ve karakterden karaktere değişimler bulunmaktadır (Tekel ve ark. 2003). Araştırmada süt verimi ve kalite özellikleri için hesaplanan tanımlayıcı değerler Çizelge 1'de verilmiştir. Değerlendirmeye alınan sürüde laktasyonun farklı dönemlerinde yapılan kontrol sağımları sonucu bulunan ortalama günlük süt verimi ve değişim sinırları 495.5 g/gün ve 103.6 1554.0 g/gün arasında çok geniş bir varyasyon gösterirken, laktasyon süt verimi için bu değerler sirasıyla $101.4 \mathrm{~kg}$ ve 63.71 - $185.31 \mathrm{~kg}$ bulunmuştur. SHS için gerçek değerlerden hesaplanan; ortalama, en düşük ve en yüksek değerler ise sırasıyla 49.968, 25.231 ve 8.000 .000 adet/ml,'dir. SHS için veriler normal dağılmadığı varyasyon katsayısı ve medyan değerinden açıkça görülmektedir. Çünkü normal dağılım gösteren serilerde ortalama ve medyan birbirine yakın olmasından dolayı varyans analizi yapabilmek için SHS değerlerine logaritmik dönüşüm uygulanmış ve LogSHS için veri normal dağılım gösterdiği görülmüştür.

Koyun sütünün makro ve mikro besin içeriği, temel üretim faktörlerine bağlıdır. Bunlar; genotip, yaş, laktasyon sırası, besleme, sağım, sağlık uygulamaları, iklim koşulları, sosyal ve ekonomik çevre olarak suralanmaktadır (Morand-Fehr ve ark. 2007). Sütteki yağ, yağsız kuru madde, protein ve laktoz oranları sirasiyla \%7.7, \%11.2, \%5.8 ve \%4.5 olarak bulunmuştur. Diğer taraftan sütteki yoğunluk ve $\mathrm{pH}$ değerleri ise sirasiyla $33,4 \mathrm{~g} / \mathrm{cm}^{3}$ ve 6,9 olarak saptanmıştır. Ele alınan özelliklerin önemli bir kısmında minimum ve maksimum değerler arasında geniş bir varyasyon olduğu görülmektedir. belirlenemeyeceğinden hareketle günlük süt verimlerinin belirlenmesi 6 . dönemden itibaren kuzular ile koyunlar birbirlerinden tamamen ayrılması ile başlanmıştır. Günlük süt verimi ile ilgili sonuçlar araştırıcıların yaptığı çalışmalar ile farklılık gösterebilmektedir. Ancak burada unutulmaması 
gereken kontrol dönemleri ve değerlendirme yöntemi ve irkların farklı olmasının bunda etkili olabileceğidir.

Koyunların laktasyon dönemi başlangicında hesaplanan canlı ağırlık değerleri bakımından sürü ortalamasından yüksek canlı ağırlığa sahip olan koyunların ortalamanın altında kalan koyunlara göre önemli bir farklılık yaratmadığı bulunmuştur (Çizelge 2). Analar için doğum tipinin süt verimi özellikleri üzerinde önemli bir etkisi olmamakla birlikte, bu konuyla ilgili yapılan bir çalışmada, ikiz doğuranlarda gözlemlenen daha yüksek süt verimi, koyunların meme bezlerinin, ikiz doğuranların tekiz doğuranlara göre daha sık emilmesinden dolayı yüksek çıktığı ifade edilmektedir (Banchero ve ark. 2004).

Kıvırcık koyunlarında laktasyon süt verimi değerinin $(101.4 \mathrm{~kg})$ bu konuda yapılan diğer çalışmaların sonuçlarına göre daha yüksek olduğu bulunmuştur. $\mathrm{Bu}$ kapsamda Kıvırcık koyununun laktasyon süt verimini Altınel ve ark. (2000) $82.85 \mathrm{~kg}$ Ceyhan ve ark. (2007) 41.8 kg Altınçekiç ve Koyuncu (2011) $42.23 \mathrm{~kg}$ olarak bildirmişlerdir. Mevcut çalışma ile bildirilen bu çalışmalara arasındaki farklılıklar yıl, farkından yada sistem farkından kaynaklanmış olabilir. Ekstansif yetiştiricilikte yağışın miktarı ve zamanı mera bitkilerinin kompozisyonunu ve mera verimliliğini etkileyebilmektedir. Ayrıca mevcut çalışmada laktasyon hesaplamasında doğumdan sütten kesime kadarki dönemde hayvanların ilk kontroldeki kadar süt vermiş oldukları varsayıldığı için süt verimi biraz daha yüksek hesaplanmış olabilir. Yılmaz ve Altın (2004) Kıvırcık koyunlarında sağılan süt veriminin 95 günlük bir dönemde 44.80 litre olduğunu ve toplam süt veriminin ancak \%47'sinin yetiştiriciler tarafindan değerlendirildiğini tespit etmişlerdir. Özet olarak sütten kesim ve buna bağlı olarak da sağım süreleri ırk, bölge ve işletmeler bazında süt verimini etkileyebilmektedir. Mevcut çalışmada yaklaşık 5 ay olarak tespit edilen laktasyon süresi aynı ırk için Altınçekiç ve Koyuncu (2011) tarafından 65-70 gün, olarak ifade ettikleri süreden daha uzundur. Mevcut çalışmada yönetsel bazı sorunların yaşanması nedeni ile süt verimi daha erken dönemde düşüş eğilimine girmiş laktasyonun sonlandırılmasına neden olmuştur.

Araştırmada bulunan günlük süt verimi değerleri genel olarak yerli ırklar için belirtilen değerlere yakın olmakla birlikte, laktasyon süt veriminin günlük ortalama süt verimi ve laktasyon süresi ile de çok yakın ilişki içinde olduğu da unutulmamalıdır. Koyunlar birinci doğumda en az gelişim ve büyüme, ikinci doğumda olanlar biraz daha gelişmiş ve üçüncü doğumda laktasyon sırasında en gelişmiş meme yapısına sahiptirler. Meme yapıları koyunların pik laktasyon süt verim dönemlerinden sonra özelliklerini kaybetmeye başlamaktadır.

Sütlerdeki LogSHS değerine kontrol döneminin etkisi istatistiki olarak önemli $(\mathrm{P}<0.01)$, canlı ağırlık ve doğum tipinin etkisi ise önemsiz bulunmuştur. Sütte bulunan somatik hücre sayısı, hayvanların memelerinin sağllğg 1 noktasında bilgi veren önemli bir göstergedir. Protein, yağ ve laktozun sentezlenmesinden sorumlu olan meme bezi hücrelerin zarar görmesi SHS'nın artmasına neden olabilmektedir (Schallibaum, 2001). Sütteki SHS'nın istenilen değerden yüksek olması insan sağlığını da etkilemektedir. Sürüde bulunan LogSHS değeri, Zom ve Morkaraman sütlerindeki 9.56 ve 7.99 değerlerinden düşük (Akça ve Bakı, 2017; Çelik ve Özdemir, 2003) bulunurken, McKusick ve ark. (2000) Doğu Friz ırkı koyunları için bildirilen 4.90 değerine benzer olduğu saptanmıştır. Bu değerin arzu edilen düzeylerde çıkması işletmedeki bakım, besleme, sağlık koruma ve sağım hijyeni ile çok yakın ilişkilidir. Raynal-Ljutovac ve ark. (2007), irk, verim, laktasyon dönemi, doğum şekli, günlük, aylık ve mevsimsel değişimler, koyun sütlerindeki SHS değişikliklere önemli ölçüde katkıda bulunduğunu ifade etmektedirler.

Sütün yağ içeriği, bakım besleme gibi çevre faktörlerine bağlı olarak süt kompozisyonunda en fazla değişim gösteren bir bileşendir. Kontrol dönemin yağ oranına etkisi istatistiki olarak önemli $(\mathrm{P}<0.01)$, canlı ağırlık ve doğum tipinin etkisi ise önemsiz bulunmuştur. En yüksek yağ oranı laktasyonun son döneminde ölçülmüştür. Bu durum süt verimi ile yağ oranı arasındaki ters ilişkiyi göstermesi açısından dikkate değerdir. Rasyonun içeriği de bu değişime katkı sağlayan önemli faktörlerden biridir (Assenat, 1991). Yüksek içerikli lif/enerji ile mera beslemesi sütte yă̆ artışına neden olurken, rasyonda yoğun yemin dahil edilmesiyle yağ azalmaktadır (Sanz Sampelayo ve ark. 2007). Araştırma sürüsünde buna benzer durumlar belli dönemlerde yaşanmıştır. Dönemler itibariyle yağ oranının laktasyonun ilerlemesi ile arttığı, ancak bu artışın düzgün olmadığı görülmektedir.

Kıvırcık koyunlarında ortalama yağ oranı \%7.7 olarak saptanmıştır. Yağ sütün içerdiği en önemli maddelerden olup, süte genellikle içerdiği yağ miktarı dikkate alınarak değer verilmektedir. Bu değerin ortalama \%6.99 civarında olduğu ifade edilmektedir (Barłowskave ark. 2011; Kiper, 2016). Diğer çalışmalarda ise Abd Allah ve ark. (2011) Rahmani ve Sakız koyunlarda yağ oranını \% 5.62 ve \% 4.73; Sezenler ve ark. (2016) Bandırma koyunlarında \% 5.26, Çelik ve Özdemir (2003) ve Yılmaz ve ark.(2011) Morkaraman ırkı koyunlarda yağ oranını sırasıyla $\% 5.30$ ve \%6.31 olarak bulmuşlardır. Sürüdeki koyunların yağ oranının yüksek çıkmasının başlıca nedenleri olarak meraya ek olarak yoğun ek yemlemenin azaltılmış olması ve laktasyonun sonuna doğru sağımın günde ikiden bire düşürülmesinin etkili olduğu düşünülmektedir. 
Çizelge 2. Süt verim özelliklerini etkileyen faktörler

Table 2. Factors fffecting milk yield traits

\begin{tabular}{|c|c|c|c|c|c|}
\hline & $\begin{array}{l}\text { Verim, g gün }{ }^{-1} \\
\text { Yield, g day }{ }^{-1}\end{array}$ & $\begin{array}{l}\mathrm{LSV}, \mathrm{kg} \\
L M Y, \mathrm{~kg}\end{array}$ & $\begin{array}{l}\operatorname{LogSHS} \\
\log S C C\end{array}$ & $\begin{array}{l}\text { Yağ, \% } \\
\text { Fat, \% }\end{array}$ & $\begin{array}{l}\text { Yağsiz KM, \% } \\
\text { Solids non fat, \% }\end{array}$ \\
\hline $\mathrm{R}^{2}, \%$ & 59.21 & 4.88 & 22.19 & 36.51 & 15.09 \\
\hline $\begin{array}{l}\text { Önemlilik } \\
\text { Significance } \\
\text { Dönemler } \\
\text { Periods }\end{array}$ & $* *$ & & $* *$ & $* *$ & $* *$ \\
\hline D1 & & & $5.4 \pm 0.11^{\mathrm{a}}$ & $7.0 \pm 0.28^{\mathrm{d}}$ & $10.8 \pm 0.11^{\mathrm{e}}$ \\
\hline D2 & & & $4.9 \pm 0.10^{\mathrm{bc}}$ & $7.0 \pm 0.18^{\mathrm{d}}$ & $11.2 \pm 0.12^{\mathrm{bcd}}$ \\
\hline D3 & & & $5.1 \pm 0.14^{\text {abc }}$ & $5.6 \pm 0.33^{\mathrm{e}}$ & $11.7 \pm 0.08^{\mathrm{a}}$ \\
\hline D4 & & & $4.9 \pm 0.10^{\mathrm{bc}}$ & $5.6 \pm 0.20^{\mathrm{e}}$ & $11.7 \pm 0.08^{\mathrm{a}}$ \\
\hline D5 & & & $5.0 \pm 0.10^{\mathrm{bc}}$ & $7.1 \pm 0.26^{\mathrm{d}}$ & $11.5 \pm 0.10^{\mathrm{ab}}$ \\
\hline D6 & $819.3 \pm 39.23^{\mathrm{a}}$ & & $5.1 \pm 0.09^{\mathrm{abc}}$ & $7.7 \pm 0.22^{\text {cd }}$ & $11.1 \pm 0.11^{\text {cde }}$ \\
\hline D7 & $726.6 \pm 35.20^{\mathrm{a}}$ & & $5.1 \pm 0.12^{\mathrm{ab}}$ & $7.8 \pm 0.34^{\mathrm{cd}}$ & $11.1 \pm 0.10^{\text {bcde }}$ \\
\hline D8 & $573.9 \pm 29.12^{\mathrm{b}}$ & & $4.7 \pm 0.14^{\mathrm{c}}$ & $8.8 \pm 0.25^{\mathrm{b}}$ & $10.7 \pm 0.09 \mathrm{e}$ \\
\hline D9 & $332.3 \pm 23.14^{\mathrm{c}}$ & & $4.9 \pm 0.12^{\mathrm{bc}}$ & $8.3 \pm 0.17^{\mathrm{bc}}$ & $10.9 \pm 0.09^{\mathrm{de}}$ \\
\hline D10 & $318.6 \pm 26.93^{c}$ & & $4.9 \pm 0.11^{\mathrm{d}}$ & $8.8 \pm 0.23^{\mathrm{b}}$ & $11.1 \pm 0.12^{\mathrm{de}}$ \\
\hline D11 & $202.4 \pm 24.62^{\mathrm{d}}$ & & $5.3 \pm 0.12^{\mathrm{ab}}$ & $9.8 \pm 0.33^{\mathrm{a}}$ & $11.4 \pm 0.22^{\mathrm{abc}}$ \\
\hline $\begin{array}{l}\text { Canlı ağırlık } \\
\text { Live weight }\end{array}$ & ÖD -NS & ÖD -NS & ÖD -NS & ÖD -NS & ÖD - NS \\
\hline$<54$ & $474.7 \pm 21.14$ & $99.7 \pm 8.82$ & $4.9 \pm 0.06$ & $7.6 \pm 0.14$ & $11.2 \pm 0.06$ \\
\hline$\geq 54$ & $486.1 \pm 15.72$ & $101.7 \pm 6.59$ & $5.0 \pm 0.05$ & $7.6 \pm 0.12$ & $11.2 \pm 0.05$ \\
\hline $\begin{array}{l}\text { Doğum Tipi } \\
\text { Birth type }\end{array}$ & ÖD - NS & ÖD - NS & ÖD -NS & ÖD -NS & ÖD - NS \\
\hline Tekiz (Single) & $471.8 \pm 14.40$ & $97.8 \pm 6.36$ & $4.9 \pm 0.04$ & $7.7 \pm 0.09$ & $11.1 \pm 0.04$ \\
\hline İkiz (Twin) & $489.1 \pm 22.91$ & $103.5 \pm 9.56$ & $5.0 \pm 0.07$ & $7.5 \pm 0.15$ & $11.3 \pm 0.07$ \\
\hline Genel (Overall) & $495.5 \pm 19.42$ & $101.4 \pm 4.88$ & $4.9 \pm 0.04$ & $7.7 \pm 0.10$ & $11.2 \pm 0.04$ \\
\hline
\end{tabular}

\begin{tabular}{|c|c|c|c|c|}
\hline & $\begin{array}{l}\text { Laktoz, \% } \\
\text { Lactose, \% }\end{array}$ & $\begin{array}{l}\text { Yoğunluk, } \mathrm{gcm}^{3-1} \\
\text { Density, } \mathrm{g} \mathrm{cm}^{3-1}\end{array}$ & $\begin{array}{l}\text { İletkenlik, } \mathrm{mScm}^{-1} \\
\text { Conductivity, } \mathrm{mScm}^{-1}\end{array}$ & $\mathrm{pH}$ \\
\hline $\mathrm{R}^{2}, \%$ & 18.29 & 26.37 & 9.97 & 8.58 \\
\hline $\begin{array}{l}\text { Önemlilik } \\
\text { Significance } \\
\text { Dönemler } \\
\text { Periods }\end{array}$ & $* *$ & $* *$ & $* *$ & $* *$ \\
\hline D1 & $4.44 \pm 0.014^{\mathrm{bcd}}$ & $1.032 \pm 0.0007 \mathrm{cdb}$ & $3.7 \pm 0.09^{\mathrm{cd}}$ & $6.88 \pm 0.019^{\text {cde }}$ \\
\hline D2 & $4.55 \pm 0.017 \mathrm{bc}$ & $1.034 \pm 0.0005^{\mathrm{bc}}$ & $4.4 \pm 0.16^{\mathrm{a}}$ & $6.84 \pm 0.021^{\mathrm{e}}$ \\
\hline D3 & $4.66 \pm 0.032^{\mathrm{a}}$ & $1.037 \pm 0.0005^{\mathrm{a}}$ & $3.8 \pm 0.05^{\mathrm{cd}}$ & $6.93 \pm 0.018^{\mathrm{abcd}}$ \\
\hline D4 & $4.66 \pm 0.033^{\mathrm{a}}$ & $1.037 \pm 0.0004^{\mathrm{a}}$ & $3.8 \pm 0.06^{\mathrm{cd}}$ & $6.90 \pm 0.012^{\text {bcde }}$ \\
\hline D5 & $4.50 \pm 0.010^{\mathrm{b}}$ & $1.035 \pm 0.0006^{\mathrm{ab}}$ & $3.8 \pm 0.08^{\mathrm{cd}}$ & $6.95 \pm 0.014^{\mathrm{ab}}$ \\
\hline D6 & $4.54 \pm 0.015^{\mathrm{bcd}}$ & $1.033 \pm 0.0006^{\mathrm{cd}}$ & $3.7 \pm 0.06^{\mathrm{d}}$ & $6.97 \pm 0.015^{\mathrm{a}}$ \\
\hline D7 & $4.54 \pm 0.020^{\mathrm{bcd}}$ & $1.033 \pm 0.0006^{\mathrm{cd}}$ & $3.9 \pm 0.26^{\mathrm{bcd}}$ & $6,94 \pm 0.022^{\mathrm{abc}}$ \\
\hline D8 & $4.41 \pm 0.018^{\mathrm{d}}$ & $1.031 \pm 0.0005^{\mathrm{e}}$ & $4.4 \pm 0.08^{\mathrm{ab}}$ & $6.88 \pm 0.019$ cde \\
\hline D9 & $4.43 \pm 0.019^{\mathrm{cd}}$ & $1.032 \pm 0.0004^{\mathrm{de}}$ & $4.1 \pm 0.06^{\mathrm{abc}}$ & $6.9 \pm 0.019$ abcde \\
\hline D10 & $4.40 \pm 0.020^{\mathrm{d}}$ & $1.032 \pm 0.0005^{\mathrm{de}}$ & $3.6 \pm 0.08^{\mathrm{d}}$ & $6.87 \pm 0.025^{\mathrm{de}}$ \\
\hline D11 & $4.3 \pm 0.016^{\mathrm{cd}}$ & $1.033 \pm 0.0008^{\text {cde }}$ & $4.0 \pm 0.18^{\mathrm{bcd}}$ & $6.87 \pm 0.024^{\text {cde }}$ \\
\hline $\begin{array}{l}\text { Canlı ağırlık } \\
\text { Live weight }\end{array}$ & ÖD -NS & ÖD - NS & ÖD -NS & ÖD -NS \\
\hline$<54$ & $4.55 \pm 0.019$ & $1.034 \pm 0.0003$ & $3.9 \pm 0.06$ & $6.88 \pm 0.015$ \\
\hline$\geq 54$ & $4.55 \pm 0.018$ & $1.034 \pm 0.0002$ & $3.9 \pm 0.05$ & $6.91 \pm 0.017$ \\
\hline $\begin{array}{l}\text { Doğum Tipi } \\
\text { Birth type }\end{array}$ & ÖD -NS & ÖD $-N S$ & ÖD - NS & ÖD -NS \\
\hline Tekiz (Single) & $4.55 \pm 0.020$ & $1.033 \pm 0.0002$ & $3.9 \pm 0.04$ & $6.90 \pm 0.018$ \\
\hline İkiz (Twin) & $4.55 \pm 0.018$ & $1.034 \pm 0.0003$ & $3.9 \pm 0.07$ & $6.91 \pm 0.017$ \\
\hline Genel (Overall) & $4.51 \pm 0.019$ & $1.033 \pm 0.2004$ & $3.9 \pm 0.04$ & $6.90 \pm 0.018$ \\
\hline
\end{tabular}

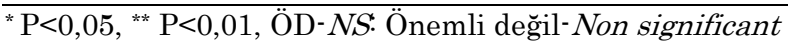

Sütün kuru madde oranı sütün besin değerini göstermesi açısından önemi büyük olup, yüksek olması arzu edilmektedir. Çalışmada ortalama yağsız kuru madde oranı \%11.2 olarak bulunmuş ve dönemler itibariyle bu değerin birbirine oldukça yakın olarak \%10.7-11.7 arasında değişmiştir. Kontrol dönemlerinin yağsız KM oranına etkisi istatistiki olarak önemli $(\mathrm{P}<0.01)$, canlı ağırlık ve doğum tipinin 
etkisi ise önemsiz bulunmuştur.

Kıvırcık koyunlarının sütlerinde bulunan yağsız KM miktarı diğer araştırmalardan elde edilen sonuçlar ile benzerdir. Çelik ve Özdemir (2003) Morkaraman koyunlarında \%11.41; Pavic' ve ark. (2002) Travnik ırkı koyunlarda bu değeri \%11.45, Şahan ve ark. (2005) ise İvesi koyunlarında \%10.93 olarak bulmuşlardır. Entansif koşullarda yetiştirilen koyunların yağsız kuru madde miktarının değişimi laktasyon süresi ile ilişkilidir. Laktasyon döneminde koyunların süt verimindeki farklılık sütün kimyasal kompozisyonunun da değişime neden olmaktadır. Bu da sütteki yağsız kuru madde miktarına yansimaktadir.

Kıvırcık koyunlarında dönemler itibariyle alınan süt örneklerinde protein oranı \%5.5-6.2 arasında değişmiş ve ortalama \%5.8 olarak hesaplanmıştır. Dönemlerin protein oranına etkisi istatistiki olarak önemli $(\mathrm{P}<0.01)$, canlı ağırlık ve doğum tipinin etkisi ise önemsiz bulunmuştur.

Sütün insan sağlığı açısından en temel bileşenlerden biri süt proteinidir. Tüketilen peynirlerin temeli bir süt proteini olan kazeine dayanmaktadır. Bu kapsamda koyun sütlerinin protein ve kazein oranları inek sütlerine göre daha yüksek olduğundan koyun sütlerinde protein oranın önemi daha da artmaktadır. Özellikle peynir randımanı açısından proteince zengin süt üreten koyun irkları bu kapsamda öne çıkmaktadır. Koyun sütünün protein oranı ortalama olarak \%5.73 dür (Barłowskave ark. 2011, Kiper 2016). McKusick ve ark. (2000) Doğu Friz koyunlarında \%6.72 ve Raicheva ve ark. (2009) ise Sakız ve Batı Balkan Dağı koyunları için sırasıyla \%5.54 ve \%5.90 olduğunu belirtmişlerdir. Diğer taraftan bazı çalışmalarda farklı ırklardaki koyun sütlerinde laktasyon boyunca protein oranının önemli ölçüde yükseldiği ifade edilmektedir (Jelinek ve ark. 1990; Stancheva ve ark., 1997; Çelik ve Özdemir 2003).

Laktoz adıyla bilinen süt şekeri doğada yalnızca sütte bulunan ve glikoz ve galaktozun birleşmesi oluşan bir disakkarittir. Kıvırcık koyunlarında bu değer ortalama \%4.51 olarak bulunmuş olup, tüm dönemler itibariyle birbirine oldukça yakın sonuçlar (\%4.404.66) vermiştir. Dönemlerin laktoz oranına etkisi istatistiki olarak önemli $(\mathrm{P}<0.01)$, canlı ağırlık ve doğum tipinin etkisi ise önemsiz bulunmuştur. Farklı çalışmalarda belirtilen ve bu çalışmada da görüldüğü gibi laktoz seviyelerinde gözlenen fark, sağım hijyeni ile de ilişkilendirilmektedir. Koyunlarda klinik ve subklinik mastitis sirasinda laktoz konsantrasyonunun azaldığı iyi bilinmektedir (Leitner ve ark. 2004). Laktoz oranı laktasyon ilerledikçe azalma eğilimi gösterdiği ifade edilmektedir (MorandFehr ve ark. 2007). Laktoz, magnezyum, kalsiyum gibi minerallerin emilimini ve $\mathrm{D}$ vitamini kullanımını desteklemesinden dolayı önemli bir süt bileşenidir. Koyun sütünde ortalama olarak \%4.75 laktoz bulunduğu belirtilmektedir (Barłowskave ark. 2011; Kiper 2016).

Sütteki yoğunluğun kontrol dönemleri itibariyle ortalaması $1.033 \mathrm{~g} / \mathrm{cm}^{3}$ olarak bulunmuştur. Dönemlerinin sütteki yoğunluğa etkisi istatistiki olarak önemli $(\mathrm{P}<0.01)$, canlı ağırlık ve doğum tipinin etkisi ise önemsiz bulunmuştur. Sütte yoğunluk ölçümleri $10-20^{\circ} \mathrm{C}$ arasında yapılmakta olup, bu değer sütteki bileşenlere bağlı olarak değişmektedir. Koyun sütünün yoğunluğu ortalama olarak 1.033-1.042 g/cm ${ }^{3}$ arasındadır. Sütte bulunan yağsız kuru madde, protein, laktoz ve mineral madde oranlarının artması sütün yoğunluğunu arttırırken, yağ oranının artması ise sütün yoğunluğunun azalmasına neden olmaktadır. Bunun nedeni süt yağının yoğunluğunun (0.93 g/ml) düşük olmasıdır. Buna bağlı olarak yağı alınmış sütlerin yoğunluğu daha yüksek (yaklaşık $1.036 \mathrm{~g} / \mathrm{ml}$ ) olmaktadır (Kiper 2016). Bu konuyla ilgili yapılan çalışmalara bakıldığında Raicheva ve ark. (2009) Sakız ve Batı Balkan Dağı koyunları için yoğunlukları sırasıyla $1.036 \mathrm{~g} / \mathrm{cm}^{3}$ ve $1.038 \mathrm{~g} / \mathrm{cm}^{3}$ ve Şahan ve ark. (2005) İvesi ırkı koyunlarda sütteki yoğunluğu $1.0334 \mathrm{~g} / \mathrm{cm}^{3}$ olarak hesaplamıştır. Aynı zamanda Yunanistan ve Brezilya'daki yerli irklar ile yapılan çalışmalarda elde edilen $1.034,1.036$ ve 1.037 $\mathrm{g} / \mathrm{cm}^{3}$ (Simos ve ark. 1996; Britio ve ark. 2006; Ivandre Antonio ve ark. 2015) değerleri araştırma sonuçlarından biraz yüksektir. Assenat (1991)'ın koyun sütü için verdiği ortalama yoğunluk $1.036 \mathrm{~g} / \mathrm{cm} 3$ olup, laktasyonun ortasina kadar artar ve laktasyon döneminin sonuna doğru azalarak $1.034 \mathrm{~g} / \mathrm{cm} 3$ yoğunluğa ulaşır ifadesi araştırma sonuçlarıyla oldukça benzerlik göstermektedir.

Sütlerdeki elektriksel iletkenlik, 1940'ların başında, mastitisin belirlenmesinde kullanılmaya başlanmıştır. Sütte bulunan en önemli anyon ve katyonlardan $\mathrm{Na}$, $\mathrm{Cl}$ ve $\mathrm{K}$ elektriksel iletkenliğin belirlenmesinde önemli işlevlere sahiptirler (Hillerton ve Walton, 1991). Bu çalışmada ortalama elektriksel iletkenlik değeri 3,9 $\mathrm{mS} / \mathrm{cm}$ olarak bulunmuştur. Laktasyon dönemlerinin elektrik iletkenlik değerine etkisi istatistiki olarak önemli $(\mathrm{P}<0.01)$, canlı ağırlık ve doğum tipinin etkisi ise önemsiz bulunmuştur. Araştırmada elde edilen ortalama elektriksel iletkenlik değeri, Peris ve ark. (1991) Manchego koyun sütünde $4.06 \mathrm{mS} / \mathrm{cm}$ ve Ayar ve ark. (1998) Karakaş ve Hamdani koyunları için bildirilen $4.030 \mathrm{mS} / \mathrm{cm}$ ve Doğan (2010) Anadolu Merinosu koyunlarında bulduğu $4.42 \mathrm{mS} / \mathrm{cm}$ değerlerinden düşüktür.

Araştırmada Kıvırcık koyunlarından alınan süt örneklerinde bulunan ortalama pH değeri 6.90 olarak bulunmuştur. Dönemin $\mathrm{pH}$ oranına etkisi istatistiki olarak önemli $(\mathrm{P}<0.01)$, canlı ağırlık ve doğum tipinin etkisi ise önemsiz bulunmuştur.

Koyun sütleri yüksek oranda kazein ve mineral madde içermesi nedeniyle koyun sütü, inek ve keçi sütüne göre daha düşük bir pH değerine sahip bulunmaktadır 
(Raynal-Ljutovac ve ark., 2007). Bu konuyla ilgili olarak Assenat (1991) Laucane koyun sütünün pH'ının genellikle 6.60 ila 6.68 arasında değiştiğini, Pugliese ve ark. (2000) Massese ırkı koyunların sütteki $\mathrm{pH}$ değerini 6.53; Akça ve Bakır (2017) ise Zom ırkı koyunlarında ise pH'ı 6.8 olarak tespit etmiştir. Mevcut çalışmadaki koyunların sütünün asitliğinin, literatürle daha önce yapılan çalışmalar ile karşılaştırıldığında biraz daha yüksek olduğu görülmektedir. Titre edilebilir asitlikteki bu artış laktik asit bakterilerince laktoz fermantasyonu sonucu laktik asit birikimini göstermektedir. Elde edilen $\mathrm{pH}$ değerlerinin diğer araştırmaların buldukları sonuçlardan yüksek çıkması koyunlardaki süt veriminin zamanla azalması, bu dönemlerde hava sıcaklığının artması ve ortam koşullarının değişmesi gibi bakım ve yönetimin uygulanabilirlik düzensizlikleri ile açıklanabilir.

\section{SONUÇ}

Kıvırcık koyunu öncelikle sütçü bir ırk olmasa da bu ırkla yapılan sınırlı çalışmalar süt veriminin iyileştirilebileceği ortaya konmuştur., Çalışmada sonuç olarak Kıvırcık koyunun sağıldığı zaman günlük ortalama 495,5 g süt verim gücüne sahip olduğu ve süt verimi ve süt kompozisyonunun laktasyon dönemlerine bağll olarak etkilendiği diğer taraftan doğum tipi ve canlı ağırlığın bu özellikler üzerine etkisinin olmadığı belirlenmiştir.

\section{TEŞEKKÜR}

Bu makale Hilal Akgün'ün yüksek lisans tezinin bir bölümünden hazırlanmış olup, araştırmayı destekleyen Bursa Uludağ Üniversitesi Bilimsel Araştırma Projeleri Komisyonuna (HDP(Z) 2017/4) teşekkür ederiz.

\section{Çıkar çatışması beyanı}

Yazarlar arasında çıkar çatışması yoktur.

\section{Yazar Katkı Oranları}

Yazarlar makaleye eşit oranda katkı sağladıklarını beyan ederler.

\section{KAYNAKLAR}

Abd Allah M, Abass SF, Allam FM. 2011. Factors affecting the milk yield and composition of Rahmani and Chios sheep. International Journal of Livestock Production, 2(3): 24-30.

Akça N, Vural ME, Karataş A, İpek P, Koncagül S, Bingöl M. 2012. Halk elinde yetiştirilen Karacadağ Zom koyununu döl ve süt verimi ile büyüme, gelişme ve dış yapı özelliklerinin belirlenmesi. TAGEM/ HAYSÜD/ 10/08/01/04. Diyarbakır.

Akça N, Bakır G. 2017. Karacadağ Zom koyununun süt bileşimi. Dicle Üniversitesi Veteriner Fakültesi
Dergisi, 10(1):19-23.

Altınel A, Güneş H, Yılmaz A, Kırmızıbayrak T, Akgündüz V. 2000. Comparison of the important production traits of Turkish Merino and indigenous Kivircık sheep breeds. İstanbul Üniversitesi Veteriner Fakültesi Dergisi, 26(2): 527-542.

Altınçekiç SÖ, Koyuncu M. 2011. Relationship between udder measurements and the linear scores for udder morphology traits in Kıvırcık, Tahirova and Karacabey Merino ewes. Kafkas Üniversitesi Veteriner Fakültesi Dergisi, 17 (1): 71-76.

Assenat L. 1991. Composición e propiedades, in: Luquet FM. (Ed.), Leche y productos lácteos: vacaoveja-cabra. Zaragoza, Spain: Acribia, p.277-313.

Ayar A, Demirulus H, Tunçtürk Y. 1998. Koyun sütlerinin elektriksel iletkenliği üzerine bazı faktörlerin etkisi. Selçuk Üniversitesi Ziraat Fakültesi Dergisi, 12 (17): 86-95.

Banchero GE, Quintans G, Martin GB, Lindsay DR, Milton JTB 2004. Nutrition and colostrum production in sheep. 1. Metabolic and hormonal responses to a high-energy supplement in the final stages of pregnancy. Reproduction, Fertility and Development, 2004, 16, 1-11.

Barłowska J, Szwajkowska M, Litwinczuk Z, Król J. 2011. Nutritional value and technological suitability of milk from various animal species used for dairy production. Comprehensive Reviews in Food Science and Food Safety, 10: 291-302.

Brito MA, González FD, Ribeiro LA, Campos R, Lacerda L, Barbosa PR, Bergmann G. 2006. Composição do sangue e do leite em ovinos leiteiros do sul do Brasil: variações na gestação e na lactação. Ciênc Rural, 36:942-948.

Ceyhan A, Erdoğan I, Sezenler T. 2007. Gen kaynağı olarak korunan Kıvırcık, Gökçeada ve Sakız koyun ırklarının bazı verim özellikleri. Tekirdağ Ziraat Fakültesi Dergisi, 4(2): 211-218.

Çelik Ş, Özdemir S. 2003. Morkaraman ırkı koyun sütlerinin bazı kimyasal ve fizikokimyasal parametrelerinin laktasyon boyunca değişimi. Atatürk Üniversitesi Ziraat Fakültesi Dergisi, 34 (3): 263-268.

Doğan Ş. 2010. Anadolu Merinosu koyunlarında meme tipleriyle sütün elektrik iletkenliği ve süt rengi arasındaki ilişkiler. Selçuk Üniversitesi, Fen Bilimleri Enstitüsü, Zootekni Anabilim Dalı, Yüksek Lisans Tezi, 40 sy.

Hillerton JE, Walton AW. 1991. Identification of subclinical mastitis with a hand- held electrical conductivy meter. Vet. Rec. 128 (22): 513-515.

Icar. 2014. International Agreement of Recording Practices ICAR Recording Guidelines Approved by The General Assembly Held in Berlin, Germany, On May.

Ivandré Antonio MJ, dos Santos JS, Grecco Costa L, Grecco Costa R, Ludovico A, de Almeida Rego FC, Walter de Santana EH. 2015. Sheep milk: physical- 
chemical characteristics and microbiological quality. ALAN, 65(3).

Jelinek P, Gajdusek S, Illek J, Helanova I, Hlusek J. 1990. Changes in composition and characteristics of ewes during lactation. Zivocisna Vyroba, 35(9), 803815.

Kiper İ. 2016. Karayaka ırkı koyunlarda laktasyon sayısının süt verimine ve süt özelliklerine etkileri. Ordu Üniversitesi, Fen Bilimleri Enstitüsü, Zootekni Anabilim Dalı, Yüksek Lisans Tezi, 41 sy.

Leitner G, Chaffer M, Shamay A, Shapiro F, Merin U, Ezra E, Saran A, Silanikove N. 2004. Changes in milk composition as affected by subclinical mastitis in sheep. J. Dairy Sciences, 87:46-52.

McKusick BC, Berger PG, Berger YM, Thomas DL. 2000. Preliminary observations on milk flow and udder morphology traits of East Friesian crossbred dairy ewes. Proceedings of the 6th Great Lakes, Dairy Sheep Symposium, November 2-4, Guelph, Ontario, Canada.

Minitab Inc. 2014. MINITAB release 17: statistical software for windows. Minitab Inc, USA.

Morand-Fehr P, Fedele V, Decandia M, Le Frileux Y. 2007. Influence of farming and feeding systems on composition and quality of goat and sheep milk. Small Ruminant Research, 68:20-34.

Park YW, Juarez M, Ranos M, Heanlein GFW. 2007. Physico-cheminal characteristics of goat and sheep milk. Small Ruminant Research, 68: 88-113.

Pavić V, Antunac N, Mıč B, Ivanković A, Havranek JL. 2002. Influence of stage of lactation on the chemical composition and physical properties of sheep milk. Czech Journal Animal Science, 47(2): 80-84.

Peris C, Molina P, Fernandez N, Rodriguez M, Torres A. 1991. Variation in somatic cell counts, California mastitis test and electrical conductivity among various fractions of ewes milk. Journal of Dairy Science, 74: 1553-1560.

Pugliese C, Acciaioli A, Rapaccini S, Parisi G, Franci O. 2000. Evolution of chemical composition, somatic cell count and renneting properties of the milk of Massese ewes. Small Ruminant Research, 35:71-80. Raıcheva E, Ivanova T, Kıprıotıs E. 2009. Test day milk, composition and udder morphology at West Balkan Mountain Sheep and their F1 Crosses with Chios breed. Bulgarian Journal of Agricultural Science, 15 (1): 93-99.

Raynal-Ljutovac K, Park YV, Gaucheron F, Bouhallab S, 2007. Heat stability and enzymatic modifications of goat and sheep milk. Small Rumin Research, 68: 207-220.

Sanz Sampelayo MR, Chilliard Y, Schmidely P, Boza J. 2007. Influence of type of diet on the fat constituents of goat and sheep milk. Small Ruminant Research, 68:42-63.

Schallibaum M. 2001. Impact of SCC on the quality of fluid milk and cheese. National Mastitis Council, Inc. 40th Annual Meeting Proceedings. 38-46, Reno, Nevada.

Sezenler T, Ceyhan A, Yüksel MA, Koncagül S, Soysal D, Yıldırır M. 2016. Influence of Year, Parity and Birth Type on Milk Yield and Milk Components of Bandirma Sheep (German Black Head Mutton x Kıvırcık) Tarım Bilimleri Dergisi, 22: 89-98.

Simos EN, Nikolaou EM, Zoiopoulos PE. 1996. Yield, composition and certain physicochemical characteristics of milk of the Epirus mountain sheep breed. Small Ruminant Research 20:67-74.

Stancheva N, Todorova D, Petrova N. 1997. Changes in the milk yield, composition properties of milk produced by synthetic dairy ewes crosses. Zhinotnov'dni Nauki, 34(3/4), 101-103.

Şahan N, Say D, Kaçar A. 2005. Changes in chemical and mineral contents of Awassi ewes milk during lactation. Turkish Journal of Veterinary and Animal Sciences, 29: 589-593.

Tuik 2018. http://www.tuik.gov.tr/UstMenu.do? metod=temelist. (15.01.2018).

Yılmaz M, Altın T. 2004. Yetiştirici koşullarında Kıvırcık koyunların süt verim yetenekleri. 4. Ulusal Zootekni Bilim Kongresi, 11-3 Eylül 2004, Süleyman Demirel Üniversitesi, Isparta.

Yılmaz O, Çak B, Bolacalı M. 2011. Effects of lactation stage, age, birth type and body weight on chemical composotion of Red Karaman sheep milk. Kafkas Universitesi Veteriner Fakültesi Dergisi, 17 (3): 383-386. 